\title{
The Impact of Educational Games on Enhancing Elementary Stage Students' Acquisition and Retention of English Vocabulary
}

\author{
Amr Mahmoud Abdeldaim Mohamed \\ PhD Candidate Ain Shams University, Egypt; English Language Lecturer, Preparatory Year Program, NBU, Saudi Arabia \\ $\triangle$ Corresponding Author: Amr Mahmoud Abdeldaim Mohamed, E-mail: amamr83@yahoo.com
}

\section{ARTICLE INFORMATION ABSTRACT}

Received: December 17, 2020

Accepted: February 10, 2021

Volume: 3

Issue: 2

DOI: $10.32996 /$ jweep.2021.3.2.6

\section{KEYWORDS}

Educational Game Strategy,

Vocabulary Acquisition, and

Vocabulary Retention
Learning EFL vocabulary is a difficult task so that teachers try as much as possible to facilitate it for their learners. One of the best strategies that can be used is educational games strategy. The goal of this research is to check the effectiveness of using the educational games strategy in enhancing English vocabulary acquisition and retention at the First stage of basic education pupils. The study adopted the quasi-experimental pre-post test control / experimental group design. The study sample consisted of 40 pupils in sixth elementary grade and was equally divided into two groups: an experimental group and a control one. Students of the experimental group learnt vocabulary through the educational game strategy, while students in the control group received regular instruction. Tools of the study included a pre-post vocabulary achievement test and a text course for grade six named Get Ready 6. The students submitted to a pre-post vocabulary achievement test and the results indicates that there is a statistically significant difference between the mean scores of the experimental group and the control group in the pre/ post-test of English vocabulary achievement in favor of the experimental group.

\section{Introduction}

In a global economy, being able to speak another language increases one's chances of finding employment (Graddol, 2006). In order to facilitate students learning a foreign language, (Rixon, 2008) said that 'Language learning is a hard task which can sometimes be frustrating. Constant effort is required to know, produce and manipulate the target language. He also said that "Games can be at the center of teaching foreign languages". Well-chosen games have a great effect on the learning process as they give students a break and allow them to practise language skills. Games are highly motivating since they are amusing and at the same time challenging. In addition, they employ meaningful and useful language in real contexts. They also encourage and increase cooperation.

Vocabulary acquisition is only one part of second or foreign language learning, but it constitutes a large and important area nonetheless. Although vocabulary research was considered to be a Cinderella subject in the 1980s (Meara, 1980), it has seen a boom in empirical studies in the course of the 1990s and 2000s (Read, 2004, p.146; Broady, 2008, p.259; Klapper, 2008, p.173) and has "achieved a position of some salience" (Daller et al, 2007). While this is certainly a really positive development, it also means that is virtually impossible to present an overview of the whole field within the limited space of this paper. For further information on vocabulary acquisition in general a number of helpful introductions to the field can be recommended such as (Aitchison, 2003), (Milton, 2009) or (Read, 2000).

Vocabulary retention is the ability to recall or remember things after an interval of time. In the process of language teaching, retention of what has been taught (e.g. grammar rules and vocabulary) may depend on the way and the quality of teaching, the interest of the learners, or the meaningfulness of the materials" (Richards \& Schmidt, 2002, p. 457). As it is clear in the domain of vocabulary learning, the problem is not just in learning second language words; rather in remembering and recalling them.

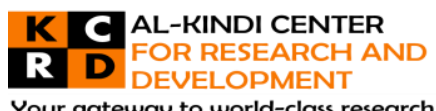

Your gateway to world-class research

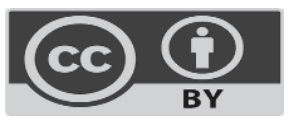

Published by Al-Kindi Center for Research and Development. Copyright (c) the author(s). This open access article is distributed under a Creative Commons Attribution (CC-BY) 4.0 license 


\subsection{Purpose of the paper}

The following paper aimed at identifying the following:

The effect of using the educational game strategy to enhance some English vocabulary skills [acquisition, retention] at the elementary stage.

\subsection{Limitations}

As with all other studies, this study has some limitations, which are highlighted here. One of the limitations is that demographic variables, such as age and gender, were not considered. Considering these variables can provide interesting findings to other research efforts. Also, the study did not consider the factor of students who were repeating the same level again. Another missing part in this study was teachers' attitudes towards enhancing their classrooms with digital tools. Including teachers attitudes might take longer time; however, it might provide more supportive information. The last limitation was the sample size. Most EFL classes have a small number of students to provide them with more educational opportunities to learn English. Getting more participants involved in the study would support it with more statistically powerful.

\subsection{Statement of the problem}

I've been teaching English for 15 years and I've noticed that students at the elementary stage encounter many problems which are related to recognizing, recalling, guessing, and producing vocabulary. The students easily forget the vocabulary newly learnt. The present study attempted to investigate the effect of educational games strategy to enhance English vocabulary acquisition and retention at elementary stage.

\subsection{The study questions}

The problem of this study can be tackled through answering the following question: What is the effect of using educational games on enhancing elementary stage students' acquisition and retention of English vocabulary?

\subsection{Significance of the study}

The study might help to achieve the following:

1. Helping students at sixth elementary stage to enhance their acquisition of some English vocabulary.

2. Helping students at sixth elementary stage to enhance their retention of some vocabulary.

3. Introducing some new teaching approaches that can help teachers to achieve English teaching goals and to develop their teaching styles in approaching vocabulary.

4. Taking the teachers and the learners away from any boring techniques that may have adverse effect on the learner's performance.

5. Drawing teachers' attention to their forgotten roles as facilitators and supervisors for their learners.

6. Drawing teachers' attention to the importance of incorporating the educational games in acquiring and developing the language skills of English.

7. Drawing attention of textbook author and program designer to the importance of using educational games.

\section{Literature of review}

One of the issues that face EFL learners, especially primary school pupils, is the subject of vocabulary learning and because vocabulary is very important in learning a language, many researchers investigate the possible factors that may help in facilitating vocabulary learning. After many studies, scholars found that pleasant and motivating atmosphere can greatly contribute in enhancing learning vocabulary process. Moreover, one of the strategies that creates funny, relaxing and attractive situation is using educational games strategy.

Recently, Argit, et al, (2020) focused on the effectiveness of games. Thus, the study aimed to find out whether there is a difference between the 4 th grades and the 7 th grades in terms of teaching vocabulary through games. A comparative research design was applied within the study. Pre-tests, post-tests, course-books, workbooks, games and worksheets were used as tools. The experimental groups studied through games and the control groups were taught through traditional methods. After implementing the strategy, the pre and post-tests' scores were calculated. According to the findings, vocabulary instruction through games was found to be more efficient than the current-curriculum methods for the 4th grades, there's no significant difference was found within the groups of the 7th grades, and using games to teach vocabulary in the 4th grades was found to be more effective compared to using educational games to teach vocabulary in the 7th grades. Studying the previous research, it has been seen that there is no comparison between primary and secondary school students' vocabulary learning levels through games. Therefore, the findings of the study are expected to shed light on this lack in the field. 
Lin, (2020) investigated the pedagogical roles of computer games. In a teacher preparation university of western Taiwan; the researchers had collected data to investigate the effectiveness of students' language learning and oral presentation improvements. It sought noteworthy cases and persuasive qualitative and numerical data from academic performance grades, implying the computer assisted learning by games contributes to improve learners' English language proficiencies for science and art and humanity majors in the teacher preparation university. By both (1) in-class instructions promoting educational games to be language learning materials by the teacher, and (2) students' applications of the video games in-class and out-class, the project had finally resulted non-English majors' developments in English language presentations, especially the Information Administration majors. It implied computer games that should be approved to be English learning materials, because it contributes to students' language proficiencies, especially in oral presentation abilities. Under the administrators' permissions by language trainers' designed syllabi and curricula, English language learners are allowed to apply in and out of classes as English learning tools.

Game-based learning is a rapidly expanding field in the 21th century, with research reports praising the motivational effects and learning outcomes of educational games. Also there have been doubts on the learning outcomes of the most seriously designed learning games. The generation that today enrolls for university programs is in general a gaming generation, and game construction students are often so called hard core gamers (Mozelius, 2018).

Chen Lee (2018) described the development of an educational game, named My-Pet-Shop, to enhance young children's learning of English vocabulary. The educational game is underpinned by an application-driven model that consists of three parts: application scenario, subject learning, and learning regulation. An empirical study is further conducted with 30 fourth-grade students to examine its influence on the aspects of performance, flow, self-regulation, and behavior related to learning. The results demonstrated that the system contributed to developed flow experience and better learning self-regulation when compared to using a quiz game system without the support of the application-driven model. In addition, behavior analysis revealed that the component of learning regulation played an important role.

Perveen et al, (2016) explored how games encouraged second language (L2) learners in retaining vocabulary because being able to use vocabulary accurately can be more important in many aspects of language fluency than merely achieving grammatical competence. Educational games can help learners acquire vocabulary unconsciously while they are engaged in the game process. Using educational games can also be very facilitating for the language teacher because of the playful atmosphere, which makes the teaching-learning process more facilitating. The researchers collected the data by selecting five English language teachers and 150 students of class 8 from various public sector schools of Lahore. The researchers employed evaluation checklist and survey questionnaire as research instruments. The results obtained after analysis revealed that games could acquaint students with new words or phrases and facilitate deep learning of vocabulary in a better and faster way in comparison to memorization. Games also help develop students' communicative competence. Most of the students agreed that new strategies via games had fruitful benefits in developing vocabulary. However, to improve certain limitations, the researchers also suggested some recommendations.

To sum up, the introduction of new technologies in society has created a need for interactive contents that can make the most of the potential that technological advances offer. Serious games such as educational games are such content: they can be defined as video games or interactive applications whose main purpose is to provide not only entertainment but also training in fields such as health, marketing, education, etc. At this time of financial, economic and social crisis people must be prepared to face the challenges of the future, and the individual values of each citizen must be joined to those of society as a whole. Serious games are the perfect tool for achieving these aims, and for transmitting contents and values attractively and efficiently. (Noemí; Máximo, 2014).

\subsection{Importance of educational games}

Educational games have started evolving rapidly over the past few years; since they have become much familiarized with computer games in their everyday lives (Guzdial \& Soloway, 2002). Additionally, educational games seem to be more apt for being used in computer programming education, since their provision of attractive graphical environments, interesting scenarios and high interactivity motivate students to learn computer programming concepts through achieving goals within an environment they are already familiar with. (Christos\& Maya, 2014)

The importance of games comes from their being a social context in which a student is encouraged to use all his linguistic knowledge actively. (Silver, 1992) says that "Games encourage, teach, and promote fluency". If not for any of these reasons, they should be used just because they help students see the beauty of a foreign language and not just problems that at times seem overwhelming. 
Uberman, (1998) states that "using games is not only a source of fun. He warned against neglecting their pedagogical value, particularly in foreign language teaching". He added that "games can lower anxiety, thus making the acquisition of input more likely. Using games in the classroom should be carefully prepared. They are not just a waste of time or a way of breaking monotony in class". This means that games are extremely motivating and entertaining, and they can give shy students more opportunity to express their opinion and feelings. They also enable students to acquire new experiences within a foreign language which are not always possible during a traditional lesson.

Not only do games motivate students in a funny way offering interactive competitive learning environments, they also can provide many other positive aspects. Games lighten the mood and this facilitates greater creativity and boost student morale and interest (Shatz \& Loschiavo, 2005). A lightened mood can negate communication apprehension. (Wyckoff and Pryor, 2003)

Educational games certainly have advantages and effectiveness in enhancing learning vocabulary acquisition and retention in various ways. First, games can bring in relaxation and fun for students, thus help them learn and retain new words more easily. Second, games usually involve friendly competition and keep learners interested as well. Educational games can create the motivation for learners of English to get involved and participate actively in the learning activities. Third, vocabulary games can bring real world context into the classroom, and develop students' use of English in a flexible, communicative way.' (Shanahan et al, 2006).

\section{Methodology}

\subsection{Design of the study}

The present study has two-group pre/post test design. In this study, two intact classes were randomly selected to represent the experimental and the control groups. On the one hand, the experimental group received training using the educational games for developing their acquisition and retention of English vocabulary skills. On the other hand, students in the control group received regular instruction. A pre-/post- vocabulary achievement test was given to the two groups before and after the treatment.

\subsection{Participants}

A group of forty primary six students were randomly selected from one of the primary schools in the school year 2019-2020 [twenty students in the experimental group twenty students in the control group].

\subsection{Instruments}

The present study made use of the following an instrument and a material:

- A pre-post vocabulary achievement test.

- A text course for grade six named Get Ready 6 .

\subsubsection{The vocabulary achievement test}

\section{Objectives of the test}

A vocabulary achievement test was constructed and administered to the two groups by the researcher. The vocabulary pre- test was designed and administered to the students of the experimental and control groups to make sure that the students were at the same level of performance in vocabulary before starting the experiment. This test was based on some vocabulary from the students' book. The pre- test was also used as a post- test to measure the experimental group students' vocabulary skills, and to investigate the effect of computer-assisted program based on language games in developing the selected vocabulary skills.

\section{Validity of the test}

To ensure the validity of the pre/posttest, it was submitted to the specialized jury members in the field of curriculum and instruction to judge its items concerning the following :

- Appropriateness of the test items to students' linguistic level, or whether the items in the test were suitable for the age of the students and their stage of development.

- Clarity and linguistic correctness of the test items .

- Ability of the test items to measure the specified skills .

- Suitability of the test items to the overall aim of the test.

The following modifications were done in order to make the test more valid:

- The test questions were rearranged from the simplest to the more complex. 
- Some test items were omitted in order to make the test more appropriate in length and to avoid having more than one question measuring the same skill. The test was considered too long and this may affect students' performance on the test .

After the completion of the jury members' initial image of the test, the researcher assessed the quantitative and qualitative assessment of their opinions about the questions and the dimensions of the pre/post test.

\section{Reliability of the pre-post test}

In order to establish the reliability of the vocabulary test in the current study, it was administered to a randomly selected group of ten students who were excluded from the whole experiment. These students were randomly selected from two of the sixth year primary classes. The test - re test method was adopted. The second test was administered fifteen days or two weeks after the first application to the same twenty students. Results show that Test- Reliability coefficient was relatively high and shows that the test as a whole is reliable and can be applied on the experimental and the control groups. Therefore, the vocabulary test could be considered a reliable one for the purpose of the present study .

Table 1 : Mean, std. deviation and Std. Error Mean for English vocabulary for the piloting sample

\begin{tabular}{lllllll}
\hline $\begin{array}{c}\text { English vocabulary } \\
\text { skills }\end{array}$ & $\mathrm{N}$ & Minimum & Maximum & Mean & Std. Deviation & Std. Error Mean \\
\hline Recognition & 10 & 7.00 & 12.00 & 9.40 & 1.71 & 0.54 \\
Recall & 10 & 2.00 & 5.00 & 3.40 & 1.17 & 0.37 \\
Production & 10 & 3.00 & 8.00 & 4.50 & 1.65 & 0.52 \\
Guessing & 10 & 2.00 & 9.00 & 5.10 & 2.08 & 0.66 \\
Total & 10 & 17.00 & 34.00 & 22.60 & 4.97 & 1.57 \\
\hline
\end{tabular}

From the previous data,

- The mean of recognition is 9.40 with std. deviation 1.71

- The mean of recall is 3.40 with std. deviation 1.17

- The mean of production is 4.50 with std. deviation 1.65

- The mean of guessing is 5.10 with std. deviation 2.08

- The mean of $r$ English vocabulary is 34.00 with std. deviation 22.60

Validity statistics: To test the validity of the Skill the Comparison terminal (the Discrimination validity) this refers to the ability of the scale to distinguish between individuals.

Table 2: Difference between the first quartile and third quartile

\begin{tabular}{llllllll}
\hline \multirow{2}{*}{ Skills } & $1^{\text {st }}$ quartile & 10 & 18.00 & 0.94 & .29 & \multirow{2}{*}{3.814} & 0.000 \\
& $3^{\text {rd }}$ quartile & 10 & 29.10 & 3.34 & 1.06 & \\
\hline
\end{tabular}

There is difference between the first quartile and third quartile for all items, where the $z$ value equal respectively 3.932 , $4.192,4.077,3.954 \& 3.814$ at $p$ value less than 0.01 . This means that the Skills were able to distinguish between the views of the individuals.

\subsubsection{The Course Book}

Get Ready is a six-level English language course for Grades 4, 5 and Grade 6 of the elementary stage of Saudi Arabia's public school system. Each level of Get Ready covers one semester of the Saudi Arabian academic year. There are twelve units in the Student's Book consisting of eight presentation units and four revision units. The language in each presentation unit follows a theme, allowing the new language to be taught in context. Themes include 'Family and work', 'My plans', 'My grandfather' and 'A special day'. Themes have been chosen to meet the needs and interests of children at this level.

\section{Duration of the program}

Implementation of the study program started on the Sunday the $18^{\text {th }}$ of January 2020 and ended on the Thursday the $8^{\text {th }}$ of March 2020. 


\section{Results}

\section{Verifying the First Hypothesis}

The first study hypothesis states that: There is a statistically significant difference between the mean scores of the experimental group and the control group on the pre/ post-test of English vocabulary recognition in favor of the experimental group. To validate the study hypothesis the researcher used:

- $\quad$ The paired t test to compare between pre and post test

- $\quad$ The independent $t$ test to compare between control and experimental

Table 5 : The first hypothesis analysis

\begin{tabular}{cccccccccc}
\hline Groups & Test & $\mathbf{N}$ & Mean & $\begin{array}{c}\text { Std. } \\
\text { Deviatio } \\
\mathbf{n}\end{array}$ & $\begin{array}{c}\text { Std. } \\
\text { Error } \\
\text { Mean }\end{array}$ & $\mathbf{T}_{\text {pa. }}$ & $\begin{array}{c}\text { Effect } \\
\text { size }\end{array}$ & $\mathbf{T}_{\text {ind }}$ & Effect size \\
\hline \multirow{2}{*}{ Control } & $\begin{array}{c}\text { Pre-test } \\
\text { Post- }\end{array}$ & 20 & 8.55 & 1.57 & 0.35 & & & & \\
& $\begin{array}{c}\text { test } \\
\text { Experimental }\end{array}$ & 20 & 12.85 & 1.63 & 0.36 & 7.98 & 2.73 & & 4.42 \\
& $\begin{array}{c}\text { Pre-test } \\
\text { Post- } \\
\text { test }\end{array}$ & 20 & 9.10 & 1.74 & 0.39 & 12.2 & $6.30^{*}$ & & \\
\hline
\end{tabular}

The above table (5) indicates that there is a:

- $\quad$ significant difference between the mean scores of the control group in the pre and post-test of English vocabulary recognition in favor of the post test, where the $t$ calculated (7.98) more than $t$ tabulated (2.56) at $p$ 0.01.the effect size equal 2.73.

- $\quad$ significant difference between the mean scores of the experimental group in the pre and post-test of English vocabulary recognition in favor of the post test, where the t calculated (12.26) more than $t$ tabulated (2.56) at p 0.01.the effect size equal 6.29 .

- $\quad$ significant difference between the mean scores of the experimental group and the control group on the post-test of English vocabulary recognition in favor of the experimental group, where the $t$ calculated (9.30) more than $t$ tabulated (2.56) at $\mathrm{p}$ 0.01.the effect size equal 4.42 .

\section{Verifying the Second Hypothesis}

The second study hypothesis states that: There is a statistically significant difference between the mean scores of the experimental group and the control group on the pre/ post-test of English vocabulary recalling in favor of the experimental group .To validate the study hypothesis the researcher used:

- $\quad$ The paired t test to compare between pre and post test

- $\quad$ The independent $t$ test to compare between control and experimental

Table 6 : The second hypothesis analysis

\begin{tabular}{|c|c|c|c|c|c|c|c|c|c|}
\hline Groups & Test & $\mathrm{N}$ & Mean & $\begin{array}{l}\text { Std. } \\
\text { Deviation }\end{array}$ & $\begin{array}{l}\text { Std. Error } \\
\text { Mean }\end{array}$ & $\mathrm{T}_{\mathrm{pa}}$ & $\begin{array}{l}\text { Effect } \\
\text { size }\end{array}$ & $T_{\text {in. }}$ & $\begin{array}{l}\text { Effect } \\
\text { size }\end{array}$ \\
\hline \multirow{2}{*}{ Control } & Pre-test & 20 & 3.50 & 1.19 & 0.27 & \multirow{2}{*}{14.21} & \multirow{2}{*}{3.53} & \multirow{4}{*}{9.17} & \multirow{4}{*}{2.60} \\
\hline & Post-test & 20 & 7.70 & 0.92 & 0.21 & & & & \\
\hline \multirow{2}{*}{ Experimental } & Pre-test & 20 & 3.45 & 1.15 & 0.26 & \multirow{2}{*}{21.44} & \multirow{2}{*}{5.78} & & \\
\hline & Post-test & 20 & 10.10 & 0.72 & 0.16 & & & & \\
\hline
\end{tabular}

The above table (6) indicates that there is a:

- $\quad$ significant difference between the mean scores of the control group in the pre and post-test of English vocabulary recalling favor of the post test, where the $t$ calculated (14.21) more than $t$ tabulated (2.56) at $p$ 0.01.the effect size equal 3.53

- significant difference between the mean scores of the experimental group in the pre and post-test of English vocabulary recalling in favor of the post test, where the $t$ calculated (21.44) more than $t$ tabulated (2.56) at $p$ 0.01.the effect size equal 5.78 
- $\quad$ significant difference between the mean scores of the experimental group and the control group on the post-test of English vocabulary recalling in favor of the experimental group, where the $t$ calculated (9.17) more than $t$ tabulated (2.56) at $\mathrm{p}$ 0.01.the effect size equal 2.60

\section{Verifying the Third Hypothesis}

The third study hypothesis states that: There is a statistically significant difference between the mean scores of the experimental group and the control group on the pre/ post-test of English vocabulary production in favor of the experimental group. To validate the study hypothesis the researcher used the paired $t$ test.

Table 7 : The third hypothesis analysis

\begin{tabular}{llllllllll}
\hline Groups & Test & $\mathbf{N}$ & Mean & $\begin{array}{l}\text { Std. } \\
\text { Deviation }\end{array}$ & $\begin{array}{l}\text { Std. Error } \\
\text { Mean }\end{array}$ & $\mathbf{T}_{\mathbf{p a}}$ & $\begin{array}{l}\text { Effect } \\
\text { size }\end{array}$ & $\mathbf{T}_{\text {in. }}$ & $\begin{array}{l}\text { Effect } \\
\text { size }\end{array}$ \\
\hline \multirow{2}{*}{ Control } & $\begin{array}{l}\text { Pre-test } \\
\text { Post- }\end{array}$ & 20 & 4.10 & 1.20 & 0.27 & & & & \\
& $\begin{array}{l}\text { Post } \\
\text { Experimental }\end{array}$ & 20 & 12.15 & 0.81 & 0.18 & 30.23 & 6.70 & & \\
& $\begin{array}{l}\text { Pre-test } \\
\text { Post- }\end{array}$ & 20 & 4.70 & 1.49 & 0.33 & & & 8.38 & 2.78 \\
& test & 20 & 14.40 & 0.88 & 0.19 & 25.68 & 6.51 & & \\
\hline
\end{tabular}

The above table (7) indicates that there is a:

- significant difference between the mean scores of the control group in the pre and post-test of English vocabulary production favor of the post test, where the $t$ calculated (30.23) more than $t$ tabulated (2.56) at $p$ 0.01.the effect size equal 6.70

- significant difference between the mean scores of the experimental group in the pre and post-test of English vocabulary production, in favor of the post test, where the $t$ calculated (25.68) more than $t$ tabulated (2.56) at $p 0.01$. the effect size equal 6.51

- significant difference between the mean scores of the experimental group and the control group on the post-test of English vocabulary production, in favor of the experimental group, where the $t$ calculated (8.38) more than $t$ tabulated (2.56) at $\mathrm{p} 0.01$. the effect size equal 2.78

\section{Verifying the Fourth Hypothesis}

The fourth study hypothesis states that: There is a statistically significant difference between the mean scores of the experimental group and the control group on the pre/ post-test of English vocabulary guessing in favor of the experimental group.

To validate the study hypothesis the researcher used the paired $t$ test

Table 8 :The fourth hypothesis analysis

\begin{tabular}{llllllllll}
\hline Groups & Test & $\mathbf{N}$ & Mean & $\begin{array}{l}\text { Std. } \\
\text { Deviation }\end{array}$ & $\begin{array}{l}\text { Std. } \\
\text { Error } \\
\text { Mean }\end{array}$ & $\mathbf{t}_{\text {pa }}$ & $\begin{array}{l}\text { Effect } \\
\text { size }\end{array}$ & $\mathbf{t}_{\text {in. }}$ & $\begin{array}{l}\text { Effect } \\
\text { size }\end{array}$ \\
\hline \multirow{2}{*}{ Control } & Pre-test & 20 & 5.40 & 2.09 & 0.47 & 10.32 & 2.41 & & \\
& Post-test & 20 & 10.45 & 1.23 & 0.28 & & & 9.61 & 2.76 \\
Experimental & Pre-test & 20 & 5.95 & 2.11 & 0.47 & 14.69 & 3.74 & & \\
& Post-test & 20 & 13.85 & 0.99 & 0.22 & & & & \\
\hline
\end{tabular}

The above table (8) indicates that there is a:

- $\quad$ significant difference between the mean scores of the control group in the pre and post-test of English vocabulary guessing in favor of the post test, where the $t$ calculated (10.32) more than $t$ tabulated (2.56) at $p$ 0.01.the effect size equal 2.41 
- $\quad$ significant difference between the mean scores of the experimental group in the pre and posttest of English vocabulary guessing, in favor of the post test, where the $t$ calculated (14.69) more than $t$ tabulated (2.56) at $p$ 0.01. the effect size equal 3.74

- $\quad$ significant difference between the mean scores of the experimental group and the control group on the post-test of English vocabulary guessing, in favor of the experimental group, where the $t$ calculated (9.61) more than $t$ tabulated (2.56) at $p$ 0.01. the effect size equal 2.76

\section{Verifying the Fifth Hypothesis}

The fifth hypothesis states that: There is a statistically significant difference between the mean scores of the experimental group and the control group in the pre/ post-test of English vocabulary achievement in favor of the experimental group. To validate the study hypothesis the researcher used the paired test

Table 9 : The fifth hypothesis analysis

\begin{tabular}{|c|c|c|c|c|c|c|c|c|c|}
\hline Groups & Test & $\mathbf{N}$ & Mean & $\begin{array}{l}\text { Std. } \\
\text { Deviation }\end{array}$ & $\begin{array}{l}\text { Std. } \\
\text { Error } \\
\text { Mean }\end{array}$ & $\mathbf{T}_{\mathbf{p a}}$ & $\begin{array}{l}\text { Effect } \\
\text { size }\end{array}$ & $\mathbf{T}_{\text {in. }}$ & $\begin{array}{l}\text { Effect } \\
\text { size }\end{array}$ \\
\hline \multirow{2}{*}{ Control } & Pre-test & 20 & 22.25 & 4.72 & 1.06 & \multirow{2}{*}{19.88} & \multirow{2}{*}{4.43} & \multirow{4}{*}{13.90} & \multirow{4}{*}{5.55} \\
\hline & Post-test & 20 & 43.15 & 2.76 & 0.62 & & & & \\
\hline \multirow{2}{*}{ Experimental } & Pre-test & 20 & 23.30 & 4.37 & 0.98 & \multirow{2}{*}{28.13} & \multirow{2}{*}{8.05} & & \\
\hline & Post-test & 20 & 58.40 & 4.06 & 0.91 & & & & \\
\hline
\end{tabular}

The above table indicates that there is a:

- $\quad$ significant difference between the mean scores of the control group in the pre and post-test of English vocabulary achievement in favor of the posttest, where the $t$ calculated (19.88) more than $t$ tabulated (2.56) at $p$ 0.01.the effect size equal 4.43

- $\quad$ significant difference between the mean scores of the experimental group in the pre and post-test of English vocabulary achievement, in favor of the posttest, where the $\mathbf{t}$ calculated (28.13) more than $\mathbf{t}$ tabulated (2.56) at $p$ 0.01. the effect size equal 8.05

- $\quad$ significant difference between the mean scores of the experimental group and the control group on the pre-test of English vocabulary achievement, in favor of the experimental group, where the $\mathbf{t}$ calculated (13.90) more than $\mathbf{t}$ tabulated (2.56) at p 0.01. the effect size equal 5.55

To sum up, all the five hypotheses of the study are supported by the experimental results. The experimental group outperformed the control group in the post-test vocabulary achievement test results which proves the effect of the educational games strategy on the experimental group students' acquisition and retention of English vocabulary. In addition, the experimental group achieved tangible progress in their vocabulary acquisition after the implementation of the program.

\subsection{Discussion of the Results}

The results of the present study shows that the experimental group, which learned using the educational games outperformed the control one in the post-measurement of the vocabulary achievement and reading comprehension tests, since there were statistically significant differences at $(, 05)$ between the mean scores of the experimental group and the control group in favor of the former.

The students' progress in the post-measurement of the vocabulary achievement test could be attributed to the fact that while learning using educational games students were interested in reading about related topics to their syllabi. Students practiced various activities of vocabulary achievement.

The results of the present study showed that the experimental group outperformed the control group in the post-measurement of the vocabulary achievement test. The statistical results showed that there were statistically significant differences between the means of scores of the experimental group in their performance of each post-test compared to the pre-measurement, favoring the post-measurement. The means score of the experimental group in each test is higher than that of the control one.Hence, the significant difference, shown on the post-measurement of each test, is due to exposing this group to the educational game strategy.

This result is in line with the results of Argit, et al (2020), Lin, (2020), Mozelius, (2018) and Chen; Lee, (2018). Those results indicate that the integration of educational games into school curriculum enhances students' learning, supports students' vocabulary 
acquisition, and improves students' knowledge, understanding, motivation and achievement. The improvement achieved by the students of the current study applying the educational games could be attributed to many reasons, such us:

- The instructional material which presented via the educational games has met students' interest and needs.

- The educational games motivate the students and allow them to study the material at speed that suits their needs.

- The educational games provide information in a variety of modes, such as dynamic animations and video (illustrations) and hypertext.

- The educational games provide the students with opportunities to practice and participate during the lessons, and to share and promote their vocabulary acquisition and reading comprehension skills.

This was evident while using the educational games in teaching the course through providing the students with a variety of activities and dividing the roles among them, which allowed them to interact with each other. Providing students with a variety of activities through this application, changing the method of teaching, dividing the roles among students to improve their vocabulary achievement and reading comprehension gave them the opportunity to interact with each other and to react to the material presented to them.

Through this interaction, they created cooperative environment in which less emphasis was placed on transmitting information from the teacher and more on the student. So, the educational games adopted throughout the study as a teaching strategy which is based on this approach helped the students go through several steps.

During the experimentation, it was noticed that the participants had a positive attitude towards the educational games. For students, the vocabulary and reading comprehension activities changed the way they feel about learning these two skills, giving students new vocabularies through reading topics related to their lessons, increased their motivation and involvement, and improved their performance.

\section{Conclusion}

This paper investigated the impact of educational games strategy on elementary stage students' acquisition and retention of English vocabulary. Although there are negative aspects of educational games strategy, this strategy has benefits in learners' learning process, especially, when they are used in right way. By reviewing the literature, this study has proposed that teachers must pay attention to the time and materials during designing or selecting the game. Though educational games strategy has also disadvantages on the vocabulary learning process, using it can help children to acquire their lesson with entertainment. In using games, students are able to recall all the vocabulary without difficulty. Games are used not only for making students successful in learning English as a second language but more importantly, for motivating them and increasing the cooperation among them.

As the findings indicate, educational games strategy can be effective in vocabulary acquisition and retention. The current findings indicate that educational games strategy, due to creating an interactive and motivating context where learners can easily and subconsciously share their information, and also due to the requirements and obligations encountered by them during playing, are effective in vocabulary acquisition and retention. The students compete and cooperate with each other in an enjoyable environment. On one hand, the students became more interested in playing and they have the willing to achieve better results, and on the other hand, they tried to learn more new vocabulary in addition to the vocabulary prepared for the class. The better they play the game the sooner they acquire the new vocabulary.

\section{References:}

[1] Aitchison, J. ( 2003). Words in the mind: An introduction to the mental lexicon, 3rd edn. Malden, MA: Blackwell.

[2] Alfarah, Z., Schunemann, H. J., \& Akl, E. A. (2010). Educational games in geriatric medicine education: a systematic review. BMC Geriatr, 10, 19.

[3] Argit, G \& Demirel, E \& Köksal, Profdr Onur. (2020). Teaching vocabulary through games: A comparative study of the 4th and the 7th grades.(pp. 41-53)

[4] Broady, E. (2008). Fragmentation and consolidation: Recent articles on vocabulary acquisition. Language Learning Journal, 36(2), $259-265$.

[5] Chen, Z. (2018). Application-Driven Educational Game to Assist Young Children in Learning English Vocabulary. Educational Technology \& Society, 21(1), 70-81.

[6] Daller, H., James, M., \& Jeanine, T. (2007). "Editors' introduction Convention, terminology and an overview of the book". In Helmut Daller, James Milton \& Jeanine Treffers-Daller (eds.). Modeling and Assessing Vocabulary Knowledge. Cambridge: Cambridge University Press, 132.

[7] Ellis, R. (1994): The study of second language acquisition. Oxford: Oxford University Press.

[8] Graddol, D. (2006). English Next. Retrieved from http://englishagenda.britishcouncil.org/sites/ec/files/books-english-next.pdf

[9] Guzdial, M. and Soloway, E. (2002). Log on Education: Teaching the Nintendo Generation how to Program, Communications of the ACM, 45(4).

[10] Harb, A. (2007). The Effectiveness of Educational Games on The Sixth Graders' Achievement in English Language in Gaza Southern Governorates, M.A thesis, the Islamic University of Gaza, Gaza. 
[11] Hubbard, P., Jones, H., Thornton, B., \& Wheeler, R. (1983). A training course for TEFL. Oxford: Oxford University Press.

[12] Klapper, J. (2008). "Vocabulary Learning Strategies in Independent Second Language Learning". In Stella Hurd \& Tim Lewis (eds.). Language learn strategies in independent settings. Bristol: Multilingual Matters, 159-178.

[13] Lin, G. (2020). Game-Based English Learning. ERIC Number: ED606848 https://eric.ed.gov/?q=educational+games+LEARNIG+ENGLISH\&id=ED606848

[14] Malliarakis, C., Satratzemi, M., \& Xinogalos, S. (2014). Designing Educational Games for Computer Programming: A Holistic Framework. Electronic Journal of e-Learning, 12(3), 281-298.

[15] Meara, Paul. (1980). "Vocabulary acquisition: A neglected aspect of language learning". Language Teaching and Linguistic Abstracts 13(221246).

[16] Milton, J. (2009). Measuring second language vocabulary acquisition". Bristol: Multilingual Matters.

[17] Mozelius, Peter. (2018). Game-Construction Students Experiences of Educational Games--Gaming Outcomes and Learning Outcomes. ICTE Journal, 7(2), 5-16.

[18] Nazir, F. (2002). Vocabulary Development in El Naggar, Z. et al. Speer. Academy for Educational Development.

[19] Noemí, Peña-Miguel; Máximo, Sedano Hoyuelos. (2014). Educational Games for Learning. Universal Journal of Educational Research, 2(3), 230-238.

[20] Perveen, A., Asif, M., Mehmood, S., Khan, M. K., \& lqbal, Z. (2016). EFECTIVENESS OF LANGUAGE GAMES IN SECOND LANGUAGE VOCABULARY ACQUISITION. Science International, 28(1). 633-637

[21] Read, J. (2004). Plumbing the depth: How should the construct of vocabulary knowledge be defined? In P. Bogaards \& B. Laufer (Eds.) Vocabulary in Second Language. Amsterdam, Netherlands: J. Benjamins Publishing Co.

[22] Read, J. (2000). Assessing vocabulary". Cambridge: Cambridge University Press.

[23] Richards, J. C., \& Schmidt, R. (2002): Longman dictionary of language teaching and applied linguistics (3rd Ed.). London: Pearson Education.

[24] Rixon, S, (2008): Language Teaching Games .ELT Journal, 40(1), 62-67

[25] Shanahan, K., Hermans, C., \& Haytko, D. (2006). Overcoming Apathy and Classroom Disconnect in Marketing Courses: Employing Karaoke Jeopardy as a Content Retention Tool. Marketing Education Review, 16(1), p.85-90.

[26] Shatz, M. \& Loschiavo, F. (2005): Learning Through Laughter. Industrial Engineer, IE, 37 (9) p.66

[27] Silvers, S. (1992). "Games for the Classroom and the English Speaking Club English Teaching", Forum VOL XX, NO2.

[28] Uberman, A. (1998). The use of games for vocabulary presentation and revision. English Teaching Forum, 36(1), 20-27. Retrieved on March 10, 2020, from http://dosfan.lib.uic.edu/usia/EUSIA/forum/vols/vol36/no1/p20.htm

[29] Wallace, M. J. (1982): Teaching Vocabulary. London: Heinemann Educational Books.

[30] Wang Wen-yu. (1998). Idea strategies and English vocabulary memorizing. Foreign Language Teaching and Research, 1.

[31] Wilkins, D.(1976). Classroom techniques. In J. Dakin (Ed.), Ideas and guidance for teachers working with adults. BBC Publications.

[32] Wycoff, E. and Pryor, B. (2003). Cognitive Processing, Creativity, Apprehension and the Humorous Personality. North American Journal of Psychology, 5(1), 31-45. 